Article

\title{
Optimization of Ultrasound-Assisted Extraction on Antioxidative Activity of Malus toringoides Using Response Surface Methodology
}

\author{
Qiang Ye 1,2 Li Guo ${ }^{1,2}$, Hongmei Liu ${ }^{1,2}$, Yushi Liu ${ }^{1,2}$, Cunyan Zhang ${ }^{1,2}$, Cheng Peng 1,2, \\ Zhiming Liu ${ }^{3}$, Shan Huang ${ }^{3, *}$ and Bin $\mathrm{Li}^{3, * \mathbb{C}}$ \\ 1 The College of Pharmacy, Chengdu University of Traditional Chinese Medicine, Chengdu 611137, China; \\ strongyeah@126.com (Q.Y.); gli64@sina.com (L.G.); liuhongmei@stu.cdutcm.edu.cn (H.L.); \\ lysdd710@163.com (Y.L.); jiajia1940@126.com (C.Z.); Pengchengchengdu@126.com (C.P.) \\ 2 The Breeding Base of State Key Laboratory of Resources Systems Research and Development Utilization of \\ Chinese Herbal Medicines Constructioned by The Ministry of Science and Technology of the PRC and \\ Sichuan Province, Chengdu 611137, China \\ 3 Department of Pharmacy, Qingdao University of Science and Technology, Qingdao 266000, China; \\ lzmqust@126.com \\ * Correspondence: huangshan@qust.edu.cn (S.H.); leebin009@163.com (B.L.); Tel.: +86-136-0898-5051 (S.H.); \\ +86-156-2111-6550 (B.L.)
}

Received: 11 April 2019; Accepted: 3 May 2019; Published: 8 May 2019

\begin{abstract}
Ultrasonic-assisted extraction (UAE) was optimized using response surface methodology (RSM) to maintain the cyto-protective activity of M.toringoides against oxidative stress. The optimal conditions for UAE were a $58 \mathrm{~mL} / \mathrm{g}$ liquid-solid ratio, a $38^{\circ} \mathrm{C}$ extraction temperature, an $85 \%$ solvent concentration, and a 19-min extraction time, which resulted in a protection rate of $54.57 \%$ against hydrogen peroxide-induced oxidative stress in human umbilical vein endothelial cells (HUVECs). These results were comparable to the predicted value of $53.75 \%$. The extracts showed excellent antioxidant activity, and phlorizin was detected in the dried leaves of Malus.toringoides. The highest yield of phlorizin $(101.239 \mathrm{mg} / \mathrm{g})$ was also obtained using these conditions. Taken together, these results showed that the method successfully integrated RSM and partial least squares regression methods to optimize M.toringoides extraction to yield the highest cyto-protective activity and effectively increase the yield of phlorizin from M.toringoides.
\end{abstract}

Keywords: M.toringoides; human umbilical vein endothelial cells; ultrasonic-assisted extraction; protection rate; response surface methodology

\section{Introduction}

The leaves of M.toringoides are a source of traditional folk medicine in Tibet, China. The traditional medicine is obtained from the leaves of M.toringoides (Rehd.) Hughes or Malus tiansitoria (Batal.) Schneid, which grow on snowy mountains at an attitude of 3000 to $3700 \mathrm{~m}$ and has been used as a food source. The active compounds include phlorizin, phloretin, quercetin, isoquercitrin, rutin, and hyperin as well as others. It has been used in the treatment of hypertension, indigestion, liver injury, hyperlipidaemia, and hyperglycemia [1]. Various substances isolated from M.toringoides leaves have strong antioxidant activities, but the antioxidant activity of M.toringoides has not been formally researched [2]. Processing of M.toringoides is currently dependent upon experience, which results in a low efficiency and unstable quality of M.toringoides extractions.

Ultrasound assisted extraction (UAE) has been used for the extraction of valuable compounds from various natural sources [3-8]. UAE can enhance the extraction rate and reduce the processing 
time [9-12]. When UAE was compared to conventional extraction methods, it was found to be a faster, more efficient, and solvent-saving technique [13-17]. Therefore, UAE is considered a convenient method for the extraction of bioactive compounds from food systems, and UAE methods can be optimized using mathematical models [18-20].

As a statistical experimental protocol, response surface methodology (RSM) is used to analyze empirical models that describe the effect of several independent variables on one or more dependent (response) variables, such as solvent concentration, extraction time, and their interactions on cyto-protective ability.To optimize the extraction by RSM that has been successfully employed, for example, polysaccharides and proteins from plants are optimized by RSM to determine extraction conditions that correlate with the highest biological activity [21,22]. However, few studies have been performed to optimize UAE to conserve cyto-protective effects via RSM.

Human umbilical vein endothelial cells (HUVECs) play an important role in humans, especially the regulation of cardiovascular health and the elasticity of vessels. Excessive accumulation of reactive oxygen species mainly induced oxidative stress, which is an important step in HUVEC injury [23,24]. Plants rich in antioxidants have attracted interest as strategies to counteract the injury caused by oxidative stress [25].

Therefore, the aim of this study was to optimize the conditions for rapid UAE of M.toringoides with high cyto-protective activity by using an RSM statistical approach and to compare the experimental and predicted protective effects. The extraction parameters (independent variables) included extraction time, solvent concentration, a solid-to-liquid ratio, and extraction temperature. Cell viability was assessed by measuring the cyto-protective effects on human endothelial cells against hydrogen peroxide $\left(\mathrm{H}_{2} \mathrm{O}_{2}\right)$-induced cell death using a cell viability assay. The cyto-protective assay was chosen to confirm the optimized extraction conditions. In addition, cyto-protective activity was correlated with antioxidant activity. To our knowledge, this is the first study showing optimization of the extraction processes of M.toringoides based on in vitro cyto-protective activity, as well as optimization of the active compounds in the extract.

\section{Materials and Methods}

\subsection{Plant Material}

Fresh M.toringoides was purchased from Ganzi Tibetan Autonomous Prefecture in October 2016 and identified by Professor Min Li, who is a pharmacognosist from the Department of Science of Identification of Chinese Materia Medica, School of Pharmacy, Chengdu University of Traditional Chinese Medicine (Chengdu, China). The plant was washed in distilled water and dried to remove the surface water. Then, the M.toringoides samples were dried to a constant weight.

\subsection{Chemicals and Reagents}

Several chemical reagents and solvents were used in this study. $\mathrm{H}_{2} \mathrm{O}_{2}$, ethanol, and MTT were purchased from Sigma Chemical Co. (St. Louis, MO, USA), PBS, DMEM media, and fetal bovine serum were purchased from HyClone Industries, USA. Trypsin was obtained from Biological Industries, Israel, and DMSO was obtained from MP Biomedicals.

\subsection{High-Performance Liquid Chromatography (HPLC) Analysis of M.toringoides}

Whole leaves from M.toringoides $(0.5 \mathrm{~g})$ were soaked in 40 times volume $(w / v)$ of $70 \%$ ethanol for $20 \mathrm{~min}$ at $30^{\circ} \mathrm{C}$. The main components, which are phlorizin and phloretin, were quantified by LC-DAD analysis using an Agilent $1220 \mathrm{LC}$ system. Chromatographic separation was performed using a Scienhome Kromasil C18 column $250 \times 4.6 \mathrm{~mm}^{2}$ at $35^{\circ} \mathrm{C}$ A gradient elution was performed with solvent A ( $0.1 \%$ phosphate acid) and solvent B (acetonitrile), which varied the proportion of solved $\mathrm{B}$ from 0 to $20 \%(0-30 \mathrm{~min})$. The extract and the standard were dissolved in methanol and filtered through a $0.45-\mu \mathrm{m}$ membrane (Millipore, Burlington, MA, USA) prior to injecting a volume of $20 \mu \mathrm{L}$. 


\subsection{Protection Rate of HUVECS}

The HUVECs were a kind gift from Prof. HoSub Lee (WonKwang University, Iksan, Korea). The cells were cultured in DulbCo modified EAG medium (DMEM), containing 10\% fetal bovine serum (Hyclone, Thermofisher, Beijing, China) and 1\% penicillin/streptomycin, and cultured in a humidified environment of $5 \%$ carbon dioxide at $37^{\circ} \mathrm{C}$. Cell viability was determined by the colorimetric reagent 3-(4,5-dimethylthiazole-2-yl) -2,5-diphenyltetrazolium ammonium bromide (MTT). Human umbilical vein endothelial cells (HUVECs) were inoculated into 96-well plates at a density of $1.0 \times 10^{5}$ cells $/ \mathrm{mL}$ to grow into fusion for $24 \mathrm{~h}$. The cells were pre-treated with $100 \mathrm{ug} / \mathrm{mL}$ Begonia extract for $24 \mathrm{~h}$, and then exposed to $0.2 \mathrm{mM}$ of $\mathrm{H}_{2} \mathrm{O}_{2}$ for $4 \mathrm{~h}$. As mentioned above, MTT was used to observe cell viability [26] after exposure to oxidative stress. MTT $(5 \mathrm{mg} / \mathrm{mL})$ was added to each well and incubated at $37^{\circ} \mathrm{C}$ for $4 \mathrm{~h}$. After absorbing the medium, the purple precipitates formed in living cells were dissolved in dimethyl sculfoxide. The optical density of each well was measured with a microplate reader at 490 $\mathrm{nm}$. The optical density of the control group was $100 \%$.

$$
\% \text { Protection rate }=\left(\mathrm{OD}_{\text {positive control }}-\mathrm{OD}_{\text {negative contral }}\right) /\left(\mathrm{OD}_{\text {contral }}-\mathrm{OD}_{\text {nagetive contral }}\right)
$$

\subsection{Single Factor Experiments and Response Surface Design}

The major component of the M.toringoides extract was phlorizin, according to the HPLC results. Therefore, the phlorizin content and the cyto-protective activity are the important indexes to determine the quality of M.toringoides extracts. The extraction time, extraction temperature, solvent concentration, and solvent-solid ratio are key factors that affect the extract composition. Therefore, single factor experiments of these three influencing factors were carried out. The highest phlorizin contents in M.toringoides and cyto-protective activities in the four experiments were taken as the optimal central values. These values were subsequently used to study the best processing method for M.toringoides by RSM.

Whole leaves from M.toringoides ( $0.5 \mathrm{~g}$ ) were soaked in 40 volume equivalents (mL/g) of $70 \%$ alcohol for $5 \mathrm{~min}, 10 \mathrm{~min}, 15 \mathrm{~min}, 20 \mathrm{~min}$, and $25 \mathrm{~min}$ at $30^{\circ} \mathrm{C}$ and filtered. Then, the cyto-protective activity of the extracts and the phlorizin contents were determined to obtain the best extraction time. Extraction temperature, solvent concentration, and the solvent-solid ratio were also obtained by this method.

\subsection{Extraction Method}

A total of $0.5 \mathrm{~g}$ of dried M.toringoides was weighed and transferred to a conical flask filled with ethanol. During ultrasound treatments, the desired temperature was kept constant throughout the trials. The experimental factors and their ranges, which were determined based on the preliminary single factor test runs, are given in Table 1.

Table 1. Experimental domain of the Box-Behnken design.

\begin{tabular}{cccc}
\hline \multirow{2}{*}{ Independent Variable } & \multicolumn{3}{c}{ Factor Levels } \\
\cline { 2 - 4 } & $\mathbf{- 1}$ & $\mathbf{0}$ & $\mathbf{1}$ \\
\hline $\mathrm{X}_{1}:$ Extraction time $(\mathrm{min})$ & 10 & 15 & 20 \\
$\mathrm{X}_{2}$ : Extraction Temp $\left({ }^{\circ} \mathrm{C}\right)$ & 25 & 30 & 35 \\
$\mathrm{X}_{3}:$ Solvent Concentration $(100 \%)$ & 70 & 80 & 90 \\
$\mathrm{X}_{4}$ : Solvent-Solid Ratio $(\mathrm{mL} / \mathrm{g})$ & 40 & 50 & 60 \\
\hline
\end{tabular}

\subsection{Experimental Design of Response Surface Methods}

The single factor experiment was used to study the extraction process parameters in order to obtain the best central value of phloretin content. The optimum processing conditions, including phlorizin content and cell protection rate, were determined by BBD (design expert software, trial 
version 8.0.5, Minneapolis Stat Ease Inc., Minneapolis, MN, USA). X1 (extraction time), X2 (extraction temperature), $\mathrm{X} 3$ (solvent concentration), and $\mathrm{X} 4$ (solvent-solid radio) were selected as the main factors. The design consists of 29 experiments and 5 repetitive centers, which are used to estimate the sum of squares of pure errors. Phlorizin content and cell viability were $Y 1$ and $Y 2$, respectively.

\section{Results and Discussion}

\subsection{The HPLC Analysis of M.toringoides Extracts}

As illustrated in Figure 1, phlorizin was an abundant component of M.toringoides extracts. This compound is believed to be responsible for most of the pharmacological activities, including activities against hypertension, indigestion, liver injury, hyperlipidaemia, and hyperglycemia [27]. A previous study demonstrated the antioxidant effect of phlorizin [28]. Therefore, the phlorizin content in M.toringoides is an important index.
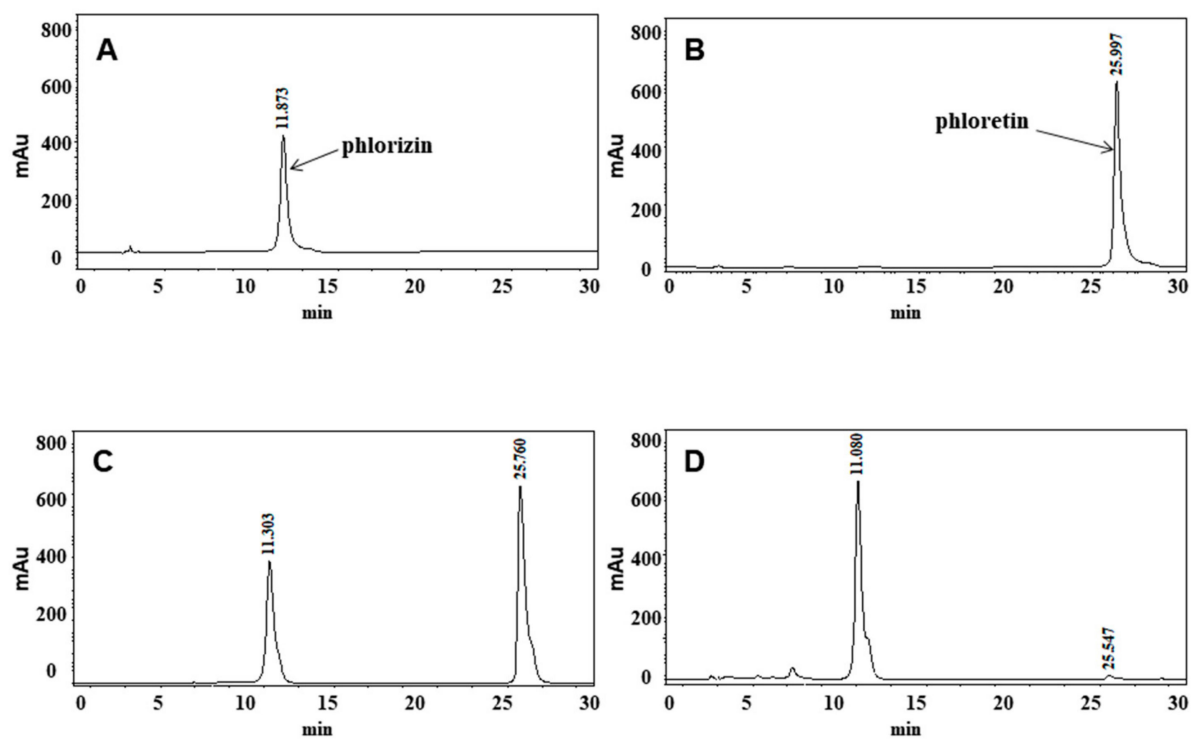

Figure 1. HPLC chromatogram of phlorizin (A). HPLC chromatogram of phloretin (B). HPLC chromatogram of phlorizin and phloretin (C). HPLC chromatogram of M.toringoides extract (D).

\subsection{Analysis of Response Surface Model}

The extraction time $(10$ and $20 \mathrm{~min})$, extraction temperature $\left(25^{\circ} \mathrm{C}\right.$ and $\left.35^{\circ} \mathrm{C}\right)$, solvent concentration (70\% and 90\%), and solvent-solid ratio $(40 \mathrm{~mL} / \mathrm{mg}$ and $60 \mathrm{~mL} / \mathrm{mg}$ ) were analyzed to determine the effect of the extraction parameters on the phlorizin content and cryo-protection of HUVECs against oxidative stress induced by hydrogen peroxide. The results are shown in Table 2.

Second order quadratic polynomial models were found to be adequate to describe the effect of independent factors on the protection rate, and the percent of phlorizin content was analyzed by the ANOVA method. The validation of the goodness of fit was determined by the lack of fit. The F-value was obtained from the lack of fit, and the p-value was obtained from the model. When the fitting of significant regression model $(p<0.05)$ and non-significant regression model $(p>0.05)$ is insufficient, the model agrees well with the experimental data. All the proposed mathematical models can be fully used to predict dependent variables as functions of independent variables. Extraction time $\left(X_{1}\right)$, extraction temperature $\left(X_{2}\right)$, solvent concentration $\left(X_{3}\right)$, and the solvent-solid ratio $\left(X_{4}\right)$ had significant linear effects on all reaction variables. 
Table 2. BB design for actual factors and results for response surface methodology.

\begin{tabular}{|c|c|c|c|c|c|c|}
\hline Run & $\begin{array}{c}\mathrm{X}_{1}: \\
\text { Extraction } \\
\text { Time (min) }\end{array}$ & $\begin{array}{c}\mathrm{X}_{2}: \\
\text { Extraction } \\
\text { Temp }\left({ }^{\circ} \mathrm{C}\right)\end{array}$ & $\begin{array}{c}X_{3} \text { : Solvent } \\
\text { Concentration }\end{array}$ & $\begin{array}{c}\mathrm{X}_{4}: \\
\text { Solvent-Solid } \\
\text { Ratio }(\mathrm{mL} / \mathrm{g})\end{array}$ & $\begin{array}{c}Y_{1}: \\
\text { Phlorizin } \\
\text { (mg/g) }\end{array}$ & $\begin{array}{c}\mathrm{Y}_{2}: \\
\text { Protection } \\
\text { Rate (\%) }\end{array}$ \\
\hline 1 & 15 & 35 & 70 & 60 & 90.77 & 42.21 \\
\hline 2 & 20 & 35 & 70 & 50 & 89.71 & 41.04 \\
\hline 3 & 15 & 35 & 90 & 60 & 96.44 & 47.72 \\
\hline 4 & 15 & 35 & 80 & 50 & 100.01 & 54.23 \\
\hline 5 & 20 & 30 & 80 & 50 & 91.43 & 42.89 \\
\hline 6 & 10 & 35 & 90 & 50 & 86.37 & 37.18 \\
\hline 7 & 10 & 40 & 80 & 50 & 87.23 & 37.90 \\
\hline 8 & 20 & 35 & 80 & 60 & 96.95 & 47.87 \\
\hline 9 & 15 & 40 & 90 & 50 & 95.23 & 47.51 \\
\hline 10 & 15 & 40 & 70 & 50 & 90.39 & 41.00 \\
\hline 11 & 15 & 30 & 80 & 40 & 88.59 & 38.79 \\
\hline 12 & 15 & 35 & 80 & 50 & 96.72 & 47.96 \\
\hline 13 & 10 & 35 & 70 & 50 & 82.15 & 30.24 \\
\hline 14 & 15 & 35 & 90 & 40 & 92.63 & 43.75 \\
\hline 15 & 10 & 35 & 80 & 60 & 86.96 & 36.85 \\
\hline 16 & 15 & 30 & 80 & 60 & 87.27 & 37.66 \\
\hline 17 & 10 & 30 & 80 & 50 & 84.75 & 35.21 \\
\hline 18 & 15 & 30 & 90 & 50 & 87.39 & 37.94 \\
\hline 19 & 15 & 30 & 70 & 50 & 84.97 & 34.23 \\
\hline 20 & 15 & 35 & 70 & 40 & 90.16 & 41.04 \\
\hline 21 & 20 & 35 & 80 & 40 & 93.45 & 45.57 \\
\hline 22 & 15 & 40 & 80 & 60 & 97.77 & 50.15 \\
\hline 23 & 15 & 35 & 80 & 50 & 97.54 & 49.72 \\
\hline 24 & 15 & 35 & 80 & 50 & 96.70 & 47.92 \\
\hline 25 & 10 & 35 & 80 & 40 & 89.02 & 40.48 \\
\hline 26 & 15 & 40 & 80 & 40 & 93.42 & 45.60 \\
\hline 27 & 15 & 35 & 80 & 50 & 97.54 & 50.41 \\
\hline 28 & 20 & 40 & 80 & 50 & 96.04 & 48.03 \\
\hline 29 & 20 & 35 & 90 & 50 & 98.77 & 52.34 \\
\hline
\end{tabular}

\subsection{Effects of Extraction Conditions on Phlorizin Extracted from M.toringoides}

The maximum phlorizin levels obtained from ultrasound assisted extraction (UAE) were $101.239 \mathrm{mg} / \mathrm{g}\left(18.82 \mathrm{~min}, 38.13{ }^{\circ} \mathrm{C}, 85.6 \%\right.$, and $\left.59.43 \mathrm{~mL} / \mathrm{g}\right)$. Based on ANOVA, the most dominant independent variable affecting the phlorizin content was the extraction time, and its $\mathrm{F}$ value was 98.3 $(p<0.0001)$. The effect of the three independent variables on the phlorizin content was expressed in quadratic terms (Table 3). The mathematical model can be expressed as follows.

$$
\begin{aligned}
& Y_{1}=97.70+4.16 X_{1}+2.97 X_{2}+2.39 X_{3}+0.74 X_{4}+0.54 X_{1} X_{2}+1.21 X_{1} X_{3}+1.39 X_{1} X_{4}+0.60 X_{2} X_{3} \\
& +1.42 X_{2} X_{4}+0.80 X_{3} X_{4}-4.24 X_{1}^{2}-4.03 X_{2}^{2}-3.97 X_{3}^{2}-1.66 X_{4}^{2}
\end{aligned}
$$

As shown in Figure 2a-c, with the extension of extraction time, the yield percentage increased and reached a maximum at $15 \mathrm{~min}$. Then the content slowly decreased. The positive linear effect of extraction temperature and its negative effect on the interaction with treatment time are shown in Figure 1a,d,e. The linear increase in phlorizin production may be due to higher system energy by higher temperature, which will enhance the release and solubility of the target compound [29]. Time/temperature interaction effect on the final result is clearly illustrated at the higher end of the temperature axis of the surface diagram, which indicates the adverse effects of long processing time (Figure 1a). In addition, as shown in Figure $2 b, d, f$, the relationship between higher yields and solvent concentration is due to an increased diffusion rate of solvents and solubility of phenazine. As shown in Figure 2c,e,f, the content of phlorizin is higher when the solvent-solid ratio increases from $40 \mathrm{~mL} / \mathrm{g}$ to $50.00 \mathrm{~mL} / \mathrm{g}$. This increase in liquid-solid ratio leads to greater osmotic pressure and contact area, 
which results in more solvents being pushed into plant substrates and facilitating the permeation of biologically active chemicals. The solvent enters through the cell wall. Empirical second-order polynomial model with experimental data applied to regression analysis.

Table 3. Analysis of variance for the fitted quadratic polynomial model for extraction of Phlorizin.

\begin{tabular}{ccccccc}
\hline Source & $\begin{array}{c}\text { Sum of } \\
\text { Squares }\end{array}$ & $d f$ & $\begin{array}{c}\text { Mean } \\
\text { Square }\end{array}$ & F-Value & $\begin{array}{c}p \text {-Value } \\
\text { Prob }>\text { F }\end{array}$ \\
\hline Model & 651.06 & 14 & 46.5 & 22.05 & $<0.0001$ & significant \\
$\mathrm{X}_{1}$-Extraction time $(\mathrm{min})$ & 207.29 & 1 & 207.29 & 98.3 & $<0.0001$ & \\
$\mathrm{X}_{2}$-Extraction temp $\left({ }^{\circ} \mathrm{C}\right)$ & 106.1 & 1 & 106.1 & 50.32 & $<0.0001$ \\
$\mathrm{X}_{3}$-solvent concentration $(100 \%)$ & 68.53 & 1 & 68.53 & 32.5 & $<0.0001$ \\
$\mathrm{X}_{4}$-Solvent-solid ratio $(\mathrm{mL} / \mathrm{g})$ & 6.59 & 1 & 6.59 & 3.13 & 0.0988 \\
$\mathrm{X}_{1} \mathrm{X}_{2}$ & 1.15 & 1 & 1.15 & 0.54 & 0.4732 \\
$\mathrm{X}_{1} \mathrm{X}_{3}$ & 5.87 & 1 & 5.87 & 2.78 & 0.1176 \\
$\mathrm{X}_{1} \mathrm{X}_{4}$ & 7.75 & 1 & 7.75 & 3.68 & 0.0758 \\
$\mathrm{X}_{2} \mathrm{X}_{3}$ & 1.45 & 1 & 1.45 & 0.69 & 0.4209 \\
$\mathrm{X}_{2} \mathrm{X}_{4}$ & 8.02 & 1 & 8.02 & 3.81 & 0.0714 \\
$\mathrm{X}_{3} \mathrm{X}_{4}$ & 2.56 & 1 & 2.56 & 1.21 & 0.2893 \\
$\mathrm{X}_{1}{ }^{2}$ & 116.8 & 1 & 116.8 & 55.39 & $<0.0001$ \\
$\mathrm{X}_{2}{ }^{2}$ & 105.59 & 1 & 105.59 & 50.07 & $<0.0001$ \\
$\mathrm{X}_{3}{ }^{2}$ & 102.37 & 1 & 102.37 & 48.55 & $<0.0001$ \\
$\mathrm{X}_{4}{ }^{2}$ & 17.97 & 1 & 17.97 & 8.52 & 0.0112 \\
Residual & 29.52 & 14 & 2.11 & & \\
Lack of Fit & 22.21 & 10 & 2.22 & 1.22 & 0.4603 & significant \\
Pure Error & 7.31 & 4 & 1.83 & & & \\
Cor Total & 680.58 & 28 & & & \\
\end{tabular}

A

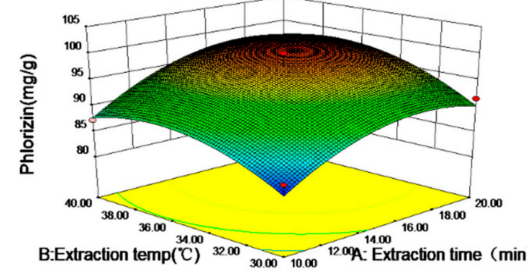

B

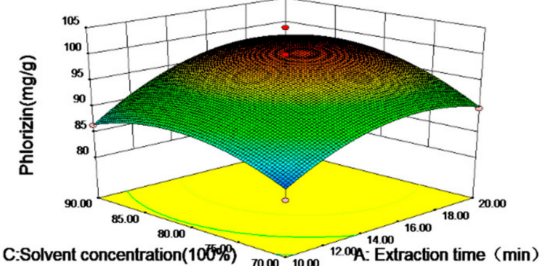

C

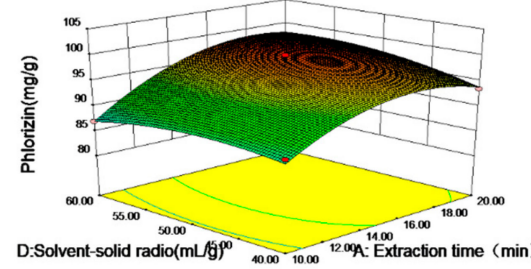

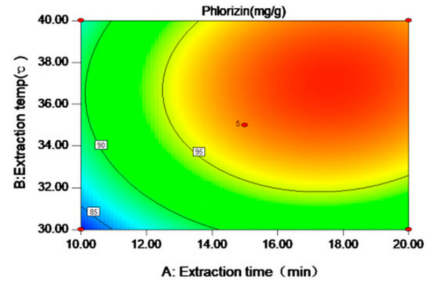
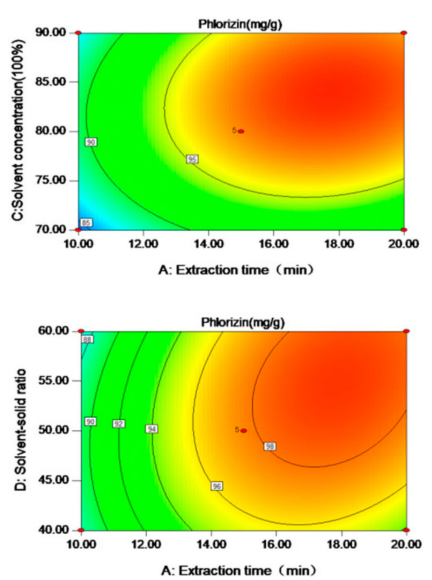

Figure 2. Cont. 
D

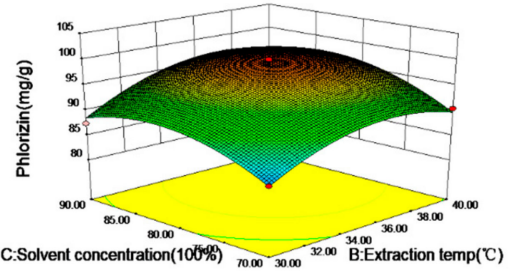

$\mathrm{E}$

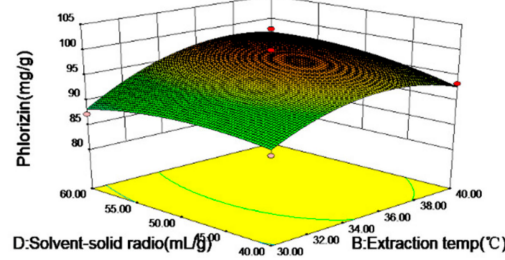

$\mathrm{F}$

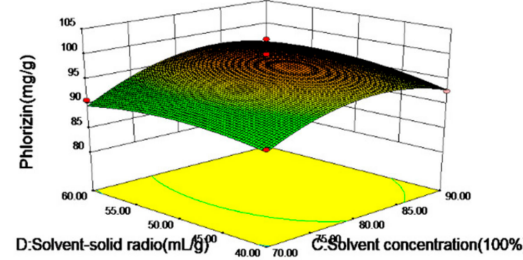

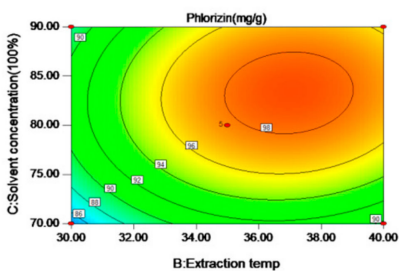
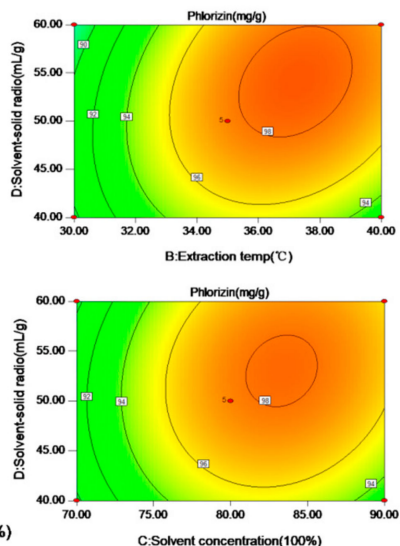

Figure 2. Response surface plots (3D) of phlorizin analysis as a function of significant interaction between factors. (A) Extraction temperature and extraction time. (B) Solvent concentration and extraction time.

(C) Solvent-solid radio and extraction time. (D) Solvent concentration and extraction temperature.

(E) Solvent-solid radio and extraction temperature. (F) Solvent-solid radio and solvent concentration.

\subsection{Determination of HUVEC Protection}

To evaluate the cyto-protective activity of M.toringoides extracts, the maximal protection rate at different processing conditions was evaluated. The best protection rate obtained as result of UAE was $80.90 \%\left(18.60 \mathrm{~min}, 37.92{ }^{\circ} \mathrm{C}, 85.09 \%\right.$, and $\left.57.47 \mathrm{~mL} / \mathrm{g}\right)$.

As shown in Table 4 , the model showed that $\mathrm{X}_{1}, \mathrm{X}_{2}, \mathrm{X}_{3}, \mathrm{X}_{1}{ }^{2}, \mathrm{X}_{2}{ }^{2}, \mathrm{X}_{3}{ }^{2}$, and $\mathrm{X}_{4}{ }^{2}$ had significant effects on the results of oxidative stress in endothelial cells $(p<0.05)$. Based on variance analysis, the second term extraction time has the greatest impact on the protection rate. As shown in Figure 3a-c, cell viability increases with the increase of extraction time, reaching its maximum in about 15 min. Then a constant value is reached and it slowly decreases. Over time, the linear increase in the protective rate may be due to the continuous cavitation and mechanical stress resulting in the release of more active substances from plant tissues [30]. The correlation of the protection rate with the independent variables was demonstrated using the quadratic statistical equation below.

$$
\begin{aligned}
& Y_{1}=50.05+4.99 X_{1}+3.62 X_{2}+3.06 X_{3}+0.60 X_{4}+0.61 X_{1} X_{2}+1.09 X_{1} X_{3}+1.48 X_{1} X_{4}+0.70 X_{2} X_{3} \\
& +1.42 X_{2} X_{4}+0.70 X_{3} X_{4}-4.87 X_{1}^{2}-4.71 X_{2}^{2}-4.80 X_{3}^{2}-2.11 X_{4}^{2}
\end{aligned}
$$


Table 4. Analysis of variance for the fitted quadratic polynomial model for protection rate.

\begin{tabular}{ccccccc}
\hline Source & $\begin{array}{c}\text { Sum of } \\
\text { Squares }\end{array}$ & $d f$ & $\begin{array}{c}\text { Mean } \\
\text { Square }\end{array}$ & F-Value & $\begin{array}{c}p \text {-Value, } \\
\text { Prob }>\boldsymbol{F}\end{array}$ \\
\hline Model & 924.53 & 14 & 66.04 & 11.33 & $<0.0001$ & significant \\
$\mathrm{X}_{1}$ : Extraction time $(\mathrm{min})$ & 298.8 & 1 & 298.8 & 51.28 & $<0.0001$ & \\
$\mathrm{X}_{2}$ : Extraction temp $\left({ }^{\circ} \mathrm{C}\right)$ & 157.47 & 1 & 157.47 & 27.02 & 0.0001 \\
$\mathrm{X}_{3}$ : Solvent concentration $(100 \%)$ & 112.12 & 1 & 112.12 & 19.24 & 0.0006 \\
$\mathrm{X}_{4}$ : Solvent-solid ratio $(\mathrm{mL} / \mathrm{g})$ & 4.36 & 1 & 4.36 & 0.75 & 0.4018 \\
$\mathrm{X}_{1} \mathrm{X}_{2}$ & 1.5 & 1 & 1.5 & 0.26 & 0.6197 \\
$\mathrm{X}_{1} \mathrm{X}_{3}$ & 4.75 & 1 & 4.75 & 0.82 & 0.3818 \\
$\mathrm{X}_{1} \mathrm{X}_{4}$ & 8.79 & 1 & 8.79 & 1.51 & 0.2396 \\
$\mathrm{X}_{2} \mathrm{X}_{3}$ & 1.96 & 1 & 1.96 & 0.34 & 0.5712 \\
$\mathrm{X}_{2} \mathrm{X}_{4}$ & 8.07 & 1 & 8.07 & 1.38 & 0.259 \\
$\mathrm{X}_{3} \mathrm{X}_{4}$ & 1.96 & 1 & 1.96 & 0.34 & 0.5712 \\
$\mathrm{X}_{1}{ }^{2}$ & 154.09 & 1 & 154.09 & 26.44 & 0.0001 \\
$\mathrm{X}_{2}^{2}$ & 143.91 & 1 & 143.91 & 24.7 & 0.0002 \\
$\mathrm{X}_{3}{ }^{2}$ & 149.39 & 1 & 149.39 & 25.64 & 0.0002 \\
$\mathrm{X}_{4}{ }^{2}$ & 28.95 & 1 & 28.95 & 4.97 & 0.0427 & \\
Residual & 81.58 & 14 & 5.83 & & & not \\
Lack of Fit & 54.96 & 10 & 5.5 & 0.83 & 0.6347 & significant \\
Pure Error & 26.62 & 4 & 6.65 & & & \\
Cor Total & 1006.11 & 28 & & &
\end{tabular}

In addition, the positive linear effect of extraction temperature and the negative effect of interaction between extraction temperature and solvent concentration are shown in Figure 3a,d,e. The linear positive correlation between cell viability and temperature may be due to higher system energy occurring at higher temperatures, which leads to more complete destruction of connective tissue and structural tissue, especially the internal force of binding and adhering analyte plant matrix molecules, which enhances the release and solubility of the E. Effective substance [31]. In addition, the extracts extracted at high temperature have higher protective activity, which is due to the increase of solvent diffusion and solubility of analytes. This is related to the antioxidant activity of solvents. The negative time/temperature interaction on the final product was observed at the higher end of the temperature axis of the surface graph, which indicates the adverse effect of long processing time (Figure 3a). As shown in Figure $3 b, d, f$, the higher protective rate associated with higher solvent concentration is due to increased solvent diffusion and enhanced solubility of biologically active chemicals in solvents. This helps obtain more effective substances. As shown in Figure $3 c, e, f$, when the liquid-solid ratio is $50 \mathrm{~mL} / \mathrm{g}$, the protection rate is higher than $40 \mathrm{~mL} / \mathrm{g}$. However, when the liquid-solid ratio is $60 \mathrm{~mL} / \mathrm{g}$, the protection rate is lower. The larger the liquid-solid ratio is, the larger the osmotic pressure and contact area are, the more solvents enter the plant matrix, and the more bioactive chemicals enter the solvents through the cell wall. 
A

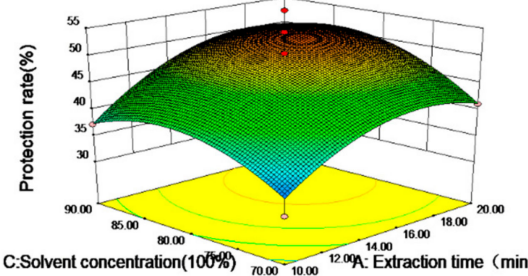

B

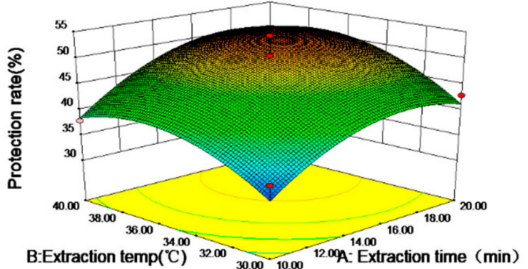

C

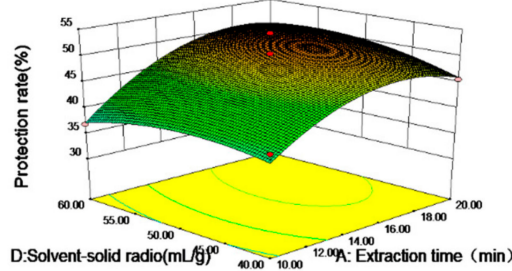

D

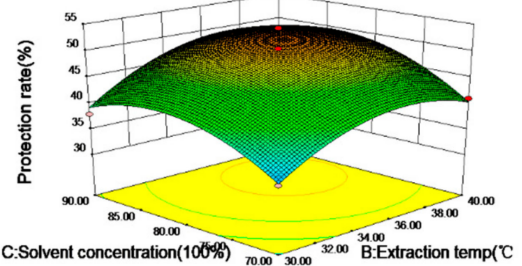

E

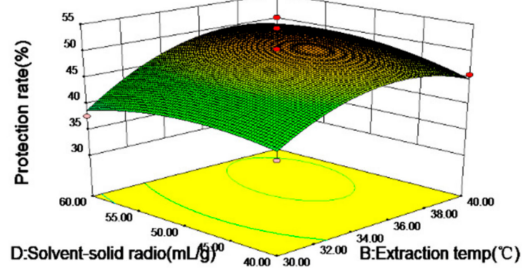

F

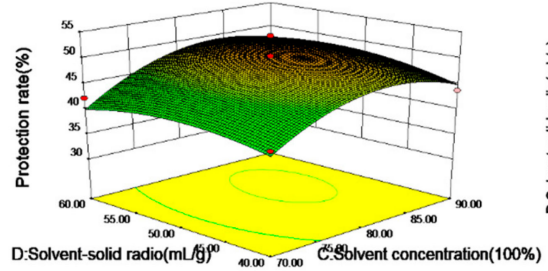

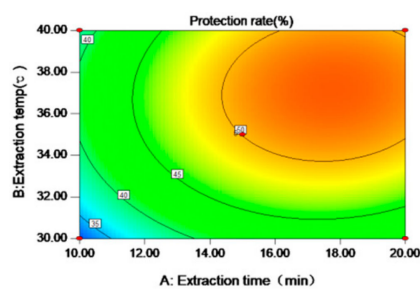
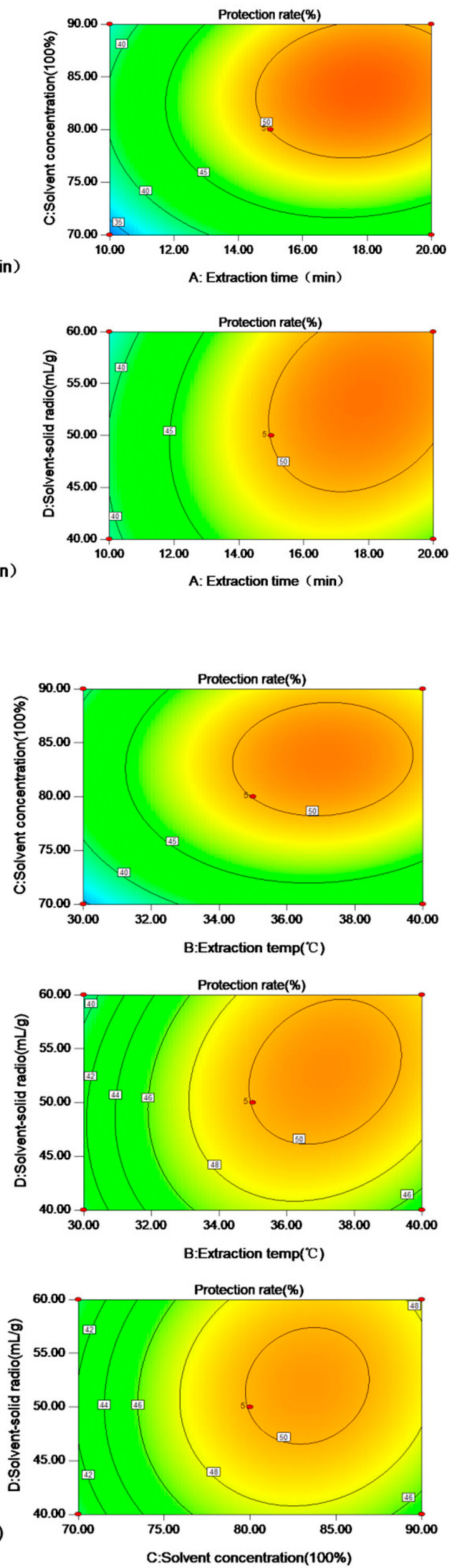

Figure 3. Response surface plots (3D) of protection rate analysis as a function of significant interaction between factors. (A) Extraction temperature and extraction time. (B) Solvent concentration and extraction time. (C) Solvent-solid radio and extraction time. (D) Solvent concentration and extraction temperature. (E) Solvent-solid radio and extraction temperature. (F) Solvent-solid radio and solvent concentration.

\subsection{Analysis of the Relationship between Protection Rate and Percentage of Phlorizin}

To investigate the relationship between the rate of HUVEC protection against $\mathrm{H}_{2} \mathrm{O}_{2}$-induced cell death and phlorizin content, 29 samples extracted by RSM were analyzed. Their relationship was revealed via a scatter plot, as shown in Figure 4. 


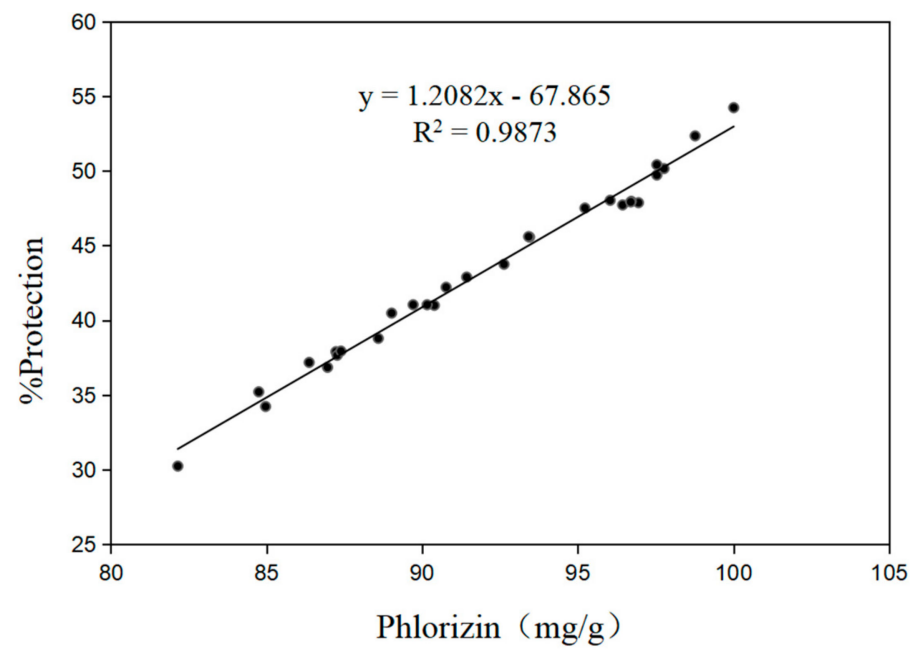

Figure 4. Scatter plot of the protection rate of human endothelial cells against hydrogen peroxideinduced oxidative stress versus phlorizin content of 29 M.toringoides.

We observed that the phlorizin content was highly correlated with the protection of HUVECs against oxidative stress, with an $R^{2}$ value of 0.9873 , which suggests that this protection might be related to the phlorizin content in M.toringoides extracts.

\section{Concluding Remarks}

In the present study, optimization of ultrasound-assisted extraction to conserve the cyto-protective effect of M.toringoides was performed with a four-variable, three-level central composite design based on response surface methodology. Compared to conventional isolation, this novel approach is less tedious and less labor intensive. The optimal extraction parameters were determined to be a $58 \mathrm{~mL} / \mathrm{g}$ liquid-solid ratio, a $38{ }^{\circ} \mathrm{C}$ extraction temperature, an $85 \%$ solvent concentration, and a 19-min extraction time. The protection rate against oxidative stress in human endothelial cells was $54.57 \pm 0.27 \%$, which was similar to the predicted protection rate of $53.75 \%$. The highest phlorizin content $(101.239 \mathrm{mg} / \mathrm{g})$ was also obtained using these conditions. We also show that phlorizin could be responsible for the cyto-protective effects of M.toringoides extracts.

Author Contributions: Conceptualization, S.H., B.L.; Funding acquisition, Q.Y.; Investigation, H.L., Y.L., C.Z., C.P., Z.L.; Supervision, L.G.; Writing—original draft, Q.Y.; Writing-review \& editing, Q.Y., S.H., B.L.

Funding: The National Key Research and Development Project (2017YFC 1701804), the Sichuan Youth Science and Technology Innovation Research (2017TD0001), the Sichuan Science and Technology Department Youth Science and Technology Innovation Research Team Project (2016TD0006), the National Key and Double First-class Construction Projects Project: Sichuan genuine medicinal materials comprehensive research and development (030041012), and the National Natural Sciences Foundation of China(81891012) funded this research.

Conflicts of Interest: The authors declare no conflict of interest.

\section{References}

1. Huang, S.; Liu, H.F.; Meng, N.; Li, B.; Wang, J.L. Hypolipidemic and Antioxidant Effects of Malus toringoides (Rehd.) Hughes Leaves in High-Fat-Diet-Induced Hyperlipidemic Rats. J. Med. Food 2017, 20, 258-264. [CrossRef]

2. Li, D.; Peng, C.; Xie, X.F. Antidiabetic effect of flavonoids from Malus toringoides (Rehd.) Hughes leaves in diabetic mice and rats. J. Ethnopharmacol. 2014, 153, 561-567. [CrossRef]

3. Wen, X.; Tian, T.; Shen, Y.; Zhang, T.; Diao, Z.W.; Zhang, Z.Q. Optimization of Ultrasonic-assisted Extraction and Antioxidant Activity of Flavonoids from Malus toringoides. Nat. Prod. Res. Dev. 2016, 28, 452-456. 
4. Arvindekar, A.U.; Laddha, K.S. An efficient microwave-assisted extraction of anthraquinones from Rheum emodi: Optimisation using RSM, UV and HPLC analysis and antioxidant studies. Ind. Crops Prod. 2016, 83, 587-595. [CrossRef]

5. Deng, J.; Zhou, X.; Xiang, C.R.; Liu, J.; Zhou, L.J.; Li, T.; Yang, Z.S.; Ding, C.B. Comparative evaluation of maceration and ultrasonic-assisted extraction of phenolic compounds from fresh olives. Ultrason. Sonochem. 2017, 37, 328-334. [CrossRef]

6. Rodrigues, M.J.; Neves, V.; Martins, A.; Rauter, A.P.; Neng, N.R.; Nogueira, J.M.F.; Varela, J.; Barreira, L.; Custódio, L. In vitro antioxidant and anti-inflammatory properties of Limonium algarvense flowers infusions and decoctions: A comparison with green tea (Camellia sinensis). Food Chem. 2016, 200, 322-329. [CrossRef]

7. Wong, K.H.; Li, G.Q.; Li, K.M.; Valentina, R.N.; Kelvin, C. Optimisation of Pueraria isoflavonoids by response surface methodology using ultrasonic-assisted extraction. Food Chem. 2017, 231, 231-237. [CrossRef]

8. Espada-Bellido, E.; Ferreiro-González, M.; Carrera, C.; Palma, M.; Barroso, C.G.; Barbero, G.F. Optimization of the ultrasound-assisted extraction of anthocyanins and total phenolic compounds in mulberry (Morus nigra) pulp. Food Chem. 2017, 219, 23-32. [CrossRef]

9. Chen, Y.; Yin, L.Z.; Zhao, L.; Shu, G.; Yuan, Z.X.; Fu, H.L.; Lv, C.; Lin, J.-C. Optimization of the ultrasound-assisted extraction of antioxidant phloridzin from Lithocarpus polystachyus Rehd. using response surface methodology. J. Sep. Sci. 2017, 10, 4329-4337. [CrossRef]

10. Mehmet, H.; Elif, M.I. Optimization of ultrasound-assisted antioxidant compounds extraction from germinated chickpea using response surface methodology. LWT-Food Sci. Technol. 2017, 77, 208-216. [CrossRef]

11. He, B.; Zhang, L.L.; Yue, X.Y.; Liang, J.; Jiang, J.; Gao, X.L.; Yue, P.X. Optimization of Ultrasound-Assisted Extraction of phenolic compounds and anthocyanins from blueberry (Vaccinium ashei) wine pomace. Food Chem. 2016, 204, 70-76. [CrossRef]

12. Florina, D.; Mircea, O. Optimization of ultrasound-assisted extraction of total monomeric anthocyanin (TMA) and total phenolic content (TPC) from eggplant (Solanum melongena L.) peel. Ultrason. Sonochem. 2016, 31, 637-646. [CrossRef]

13. Xu, D.P.; Zheng, J.; Zhou, Y.; Li, Y.; Li, S.; Li, H.B. Ultrasound-assisted extraction of natural antioxidants from the flower of Limonium sinuatum: Optimization and comparison with conventional methods. Food Chem. 2017, 217, 552-559. [CrossRef]

14. Tarun, B.; Praveen, D.; Indra, D.; Bhatt Ranbeer, S.R.; Pande, V. Optimization extraction conditions for improving phenolic content and antioxidant activity in Berberis asiatica fruits using response surface methodology (RSM). Food Chem. 2016, 207, 115-124. [CrossRef]

15. Ameer, K.; Bae, S.W.; Jo, Y.; Lee, H.G.; Ameer, A.; Kwon, J.H. Optimization of microwave-assisted extraction of total extract, stevioside and rebaudioside-A from Stevia rebaudiana (Bertoni) leaves, using response surface methodology (RSM) and artificial neural network (ANN) modelling. Food Chem. 2017, 229, 198-207. [CrossRef]

16. Chemat, F.; Tomao, V.; Virot, M. Towards the industrial production of antioxidants from food processing by-products with ultrasound-assisted extraction. Ultrason. Sonochem. 2010, 17, 1066-1074.

17. Chemat, F.; Zille, H.; Khan, M.K. Applications of ultrasound in food technology: Processing, preservation and extraction. Ultrason. Sonochem. 2016, 18, 813-835. [CrossRef]

18. Chen, F.; Sun, Y.; Zhao, G.; Liao, X.; Hu, X.; Wu, J. Optimization of ultrasound-assisted extraction of anthocyanins in red raspberries and identification of anthocyanins in extract using high-performance liquid chromatographyemass spectrometry. Ultrason. Sonochem. 2016, 14, 767-778. [CrossRef]

19. Corbin, C.; Fidel, T.; Leclerc, E.A.; Barakzoy, E.; Sagot, N.; Falguieres, A. Development and validation of an efficient ultrasound assisted extraction of phenolic compounds from flax (Linum usitatissimum L.) seeds. Ultrason. Sonochem. 2015, 26, 176-185. [CrossRef]

20. Hossain, M.B.; Brunton, N.P.; Patras, A.; Tiwari, B.; O’Donnell, C.P.; Martin-Diana, A.B. Optimization of ultrasound assisted extraction ofantioxidant compounds from marjoram (Origanum majorana L.) using responsesurface methodology. Ultrason. Sonochem. 2012, 19, 582-590. [CrossRef]

21. Liao, P.; Liu, Y.; Zhao, M.; Yang, Y.; Cui, X. The Development of Panax notoginseng Medicinal Liquor Processing Technology Using the Response Surface Method and a Study of its Antioxidant activity and Its Effects on Mouse Melanoma B16 Cells. Food Funct. 2017. [CrossRef] 
22. Norziah, M.H.; Amir, E.T.; Abidin, S.Z.; Mahmood, W.A.K.; Juliano, P. The effects of ultrasound assisted extraction on antioxidative activity of polyphenolics obtained from Momordica charantia fruit using response surface approach. Food Biosci. 2017, 17, 7-16. [CrossRef]

23. Thiruvikraman, S.V.; Guha, A.; Roboz, J.; Taubman, M.B.; Nemerson, Y.; Fallon, J.T. In situ localization of tissue factor in human atherosclerotic plaques by binding of digoxigenin-labeled factors VIIa and X. Lab. Investig. 1996, 75, 451-461. [CrossRef]

24. Wilcox, J.N.; Smith, K.M.; Schwartz, S.M.; Gordon, D. Localization of tissue factor in the normal vessel wall and in the atherosclerotic plaque. Proc. Natl. Acad. Sci. USA 1989, 86, 2839-2843. [CrossRef]

25. Westrick, R.J.; Bodary, P.F.; Xu, Z.; Shen, Y.C.; Broze, G.J.; Eitzman, D.T. Deficiency of tissue factor pathway inhibitor promotes atherosclerosis and thrombosis in mice. Cell. Physiol. Biochem. 2015, 28, 765-783. [CrossRef]

26. Kam, A.; Li, K.M.; Razmovski-Naumovski, V.; Nammi, S.; Chan, K.; Li, G.Q. Combination of TNF-A, homocyteine and afenosine exacerbated cytotoxicity in human cardiovascular and cerebrovascular endothelial cells. Cell. Physiol. Biochem. 2012, 30, 805-814.

27. Gosch, C.; Halbwirth, H.; Stich, K. Phloridzin: Biosynthesis, distribution and physiological relevance in plants. Phytochemistry 2010, 71, 838-843. [CrossRef]

28. Ehrenkranz, J.R.; Lewis, N.G.; Kahn, C.R.; Roth, J. Phlorizin: A review. Diabetes Metab. Res. Rev. 2005, 21, 31-38. [CrossRef]

29. Wong, K.H.; Razmovski-Naumovski, V.; Li, K.M.; Li, G.Q.; Chan, K. Differentiation of Pueraria lobata and Pueraria thomsonii using partial least square discriminant analysis (PLS-DA). J. Pharm. Biomed. Anal. 2013, 84, 5-13. [CrossRef]

30. Wong, K.H.; Razmovski-Naumovski, V.; Li, K.M.; Li, G.Q.; Chan, K. Differentiating Puerariae Lobatae Radix and Puerariae Thomsonii Radix using HPTLC coupled with multivariate classification analyses. J. Pharm. Biomed. Anal. 2014, 95, 11-19. [CrossRef]

31. Wong, K.H.; Razmovski-Naumovski, V.; Li, K.M.; Li, G.Q.; Chan, K. Comparing morphological, chemical and anti-diabetic characteristics of Puerariae lobatae Radix and Puerariae thomsonii Radix. J. Ethnopharmacol. 2015, 164, 53-63.

(C) 2019 by the authors. Licensee MDPI, Basel, Switzerland. This article is an open access article distributed under the terms and conditions of the Creative Commons Attribution (CC BY) license (http://creativecommons.org/licenses/by/4.0/). 